\title{
Neoliberal Forms of Capital and the Rise of Social Movement Partysim in Central America
}

Paul Almeida

University of California, Merced

palmeida@ucmerced.edu

\begin{abstract}
Historical shifts in global economic formations shape the strategies of resistance movements in the global South. Neoliberal forms of economic development over the past thirty years in Central America have weakened traditional actors sponsoring popular mobilization such as labor unions and rural cooperatives. At the same time, the free market reforms produced new threats to economic livelihood and well-being throughout the region. The neoliberal measures that have generated the greatest levels of mass discontent include rising prices, privatization, labor flexibility laws, mining projects, and free trade. This article analyzes the role of emerging antineoliberal political parties in alliance with popular movements in Central America. Countries with already existing strong anti-systemic parties in the initial phases of the global turn to neoliberalism in the late twentieth century resulted in more efficacious manifestations of social movement partyism in the twenty-first century resisting free market globalization.
\end{abstract}

KEYWORDS: Popular Resistance, Neoliberalism, Social movement Partyism, Central America, Global Capitalism

With the rise of the third world debt crisis and revolutionary political conflict in the $1980 \mathrm{~s}$, Central America transitioned from a period of state-led development to a free market social formation with relatively more democratic polities. Neoliberal forms of economic development over the past thirty years in the region have weakened traditional actors sponsoring popular mobilization such as labor unions and rural cooperatives (Silva 2012). At the same time, the free market reforms produced new threats to economic livelihoods and well-being throughout the region. The neoliberal measures that have generated the greatest levels of mass discontent include rising prices, privatization, labor flexibility laws, mining projects, and free trade (see Almeida 2014 for extensive empirical documentation). This article analyzes the role of emerging anti-neoliberal political parties in alliance with popular movements in Central America, with a special emphasis on the current period of accelerated globalization. It addresses a fundamental conundrum in the epoch of global neoliberalism: how is mass-coordinated resistance possible given economic restructuring trends away from the public sector and state infrastructure and towards private organization and consumption that exalts individualism and fragments civil society?

This work is licensed under a Creative Commons Attribution 4.0 United States License. Journal of World-Systems Research, Volume 21, Number 1, Pages 8-24 ISSN 1076-156X 


\section{The Shift to Global Neoliberalism and the rise of Social Movement Partyism}

Past scholarly attention connecting large scale economic change to mass resistance has largely focused on waves of antisystemic or social movement activity (Wallerstein 1990; Martin 2008). For example, Gunder Frank and Fuentes (1994) associated long term economic trends in Kondratieff cycle dynamics between 1780 and 1990 with the temporal grouping of major social movements around the world, including women's, ecology, peace, and peasant movements. Argarton, Choi, and Huynh (2008) uncovered clusters of similar styles of movements in their study of the "long eighteenth century" (1750-1850). In this nascent period of global capitalist development, new transnational trade networks emerged with the ascendancy of British economic hegemony. The incursion of western trade, markets, and colonial expansion into Africa, Asia, and Latin America set off similar types of religious, nationalist, anti-plantation, and de-linking collective revolts. In the late nineteenth and early twentieth centuries, Arrighi, Hopkins, and Wallerstein (1989) contend in the global North that antisystemic movements grouped at the point of production as peasants and craft labor were increasingly displaced by mechanized forms of capital. In a separate analysis of the late nineteenth century, Bush (2008) aggregates episodes of collective action responding to the imperial phase of global capital into the women's movement, abolition struggles, anti-colonial resistance, and labor/socialist mobilizations.

In more recent historical examples, Silver (2003) demonstrates trends in global labor organizing and strike activity between the late nineteenth century and the late twentieth century in rhythm with changes in capitalist production technologies and spatial distributions of assembly and manufacturing. Wallerstein (2014) viewed the clustering of radical movements around the globe in the late $1960 \mathrm{~s}$ as associated with the decline of U.S. and Soviet hegemonic power as well as the end of the Kondratieff A-phase of mid-twentieth century economic expansion. In the early neoliberal period of the late twentieth century, Walton and his collaborators' work highlights the synchronicity of austerity protest and food riots as the response to the Third World debt crisis (Udayagiri and Walton 2003). Smith and Weist (2012) also find a growth in transnational social movement organizations in the late twentieth century as a direct outgrowth and response to the social and environmental consequences of neoliberal globalization.

These ambitious studies of global economic change and antisystemic mobilizing largely focus on levels of social movement-type activity and their temporal clustering. Another related dimension of heightened mobilization in relation to world-wide economic shifts beyond clusters or waves is the form of the oppositional movements. More specifically, with the transition from state-led development to neoliberalism, an upturn of oppositional political parties organizing with popular movements has taken place. This party-popular movement alliance-or social movement partysim - may be one of the more potent forms of slowing the pace of unwanted economic changes in Polanyian terms (Silva 2012, Spalding 2014; Block and Somers 2014).

Most analyses of these anti-systemic political parties and movements focus at the national level by comparing a set of countries or concentrate on a single movement as a case study. The present study adds to these previous frameworks by analyzing the interaction of national regimes in the context of shifts in the capitalist world economy. Such an approach takes into account the transformations of the global capitalist system over time. In this case, the transition from a Keynesian model of welfare state capitalism to neoliberal forms of accumulation in the late 
twentieth century had varying impacts on the types of resistance at the national level as new economic grievances impacted the urban and rural working classes (Shefner and Stewart 2011). Indeed, Chase-Dunn (2006: 90) writes, "Under conditions of increased economic globalization the ability of national states to protect their citizens from world market forces decreases. This results in increasing inequalities within countries and increasing levels of dissatisfaction compared with the relative harmony of national integration achieved under the Keynesian regimes." The neoliberal transition also coincided with the third wave of global democracy (Huntington 1991; Markoff and White 2009). Over the past three decades, these dual pressures of neoliberal restructuring and democratization pushed the forms of anti-systemic mobilization away from armed conflict into more nonviolent forms of social movement struggle (Schock 2005; Nepstad 2011) and electoral politics (Foran 2005).

Anti-neoliberal political parties are beginning to fill an organizational void in civil society by mobilizing resistance movements against neoliberalism over a vast territorial space. These political parties directly challenge the move toward free market globalization and the corresponding state institutions that implement the economic liberalization policies (Subramaniam 2015). The new social movement political parties are also increasing their electoral fortunes as they deepen their alliance with popular movements. The alliance between oppositional parties and social movements is termed "social movement partyism" (Almeida $2006 ; 2010$ ). Organizations such as political parties and nongovernmental organizations (NGOs) need to be given more recognition for their roles in mobilizing large numbers of people in opposition to externally imposed forms of capitalism. Oppositional political parties and NGOs fill the void of labor unions, rural cooperatives and peasant associations that have been decimated by decades of labor flexibility laws and structural adjustment agreements that reduce formal employment and cut of subsidies to the rural sector. Political parties in particular, use the emerging democratic space to organize across a national landscape, while NGOs tend to work in more local environments. This provides political parties a privileged position and capacity to organize in the neoliberal era. NGOs vary in terms of their missions and capacity to serve as organizers of subaltern groups. In many contexts in the developing world, NGOs carry out the policies and frameworks of their northern donors (Bob 2005; Subramaniam 2007). NGOs in many times and places serve to de-mobilize popular classes (Hulme and Edwards 1997; Jackson 2005). Nonetheless, nongovernmental organizations in countries with an exclusive and repressive history tend to mobilize people in social movement campaigns.

Examples abound of the role of opposition political parties mobilizing large numbers of people against free market reforms in the early twenty-first century. In Greece, traditional leftist parties and the new left SYRIZIA coalition have played a critical role in mobilizing citizens and aligning with other popular sectors in the Greek anti-IMF protests between 2009 and 2015 (Kousis 2014; Diani and Kousis 2014). Similar dynamics have occurred in Spain with the rapid rise of the PODEMOS party from anti-austerity protests in the 2010s. In South America over the past two decades political parties such as the Movement toward Socialism (MAS) and the Pachakuti in Bolivia, Pachakutik in Ecuador (MPP), the Frente Amplio in Uruguay, and the Polo Democrático in Colombia have used their party structures in mobilizing large numbers of citizens against neoliberalism in alliance with popular movements (Almeida 2010). Moreover, all of the above oppositional parties also vie for state power via national elections as a new pathway for achieving structural transformation in the twenty-first century in the context of democratization and relatively competitive elections (Foran 2005). 
In countries with strong anti-systemic movements and revolutionary political parties at the dawn of the transition to neoliberalism in the $1980 \mathrm{~s}$ and $1990 \mathrm{~s}$, we would expect a more rapid and extensive resistance to neoliberal forms of capitalism. The growing trend of political parties mobilizing with social movements in the twenty-first century is a product of deepening neoliberalism with relatively more democratic polities encouraging the expansion of electoral parties.

The region's debt crisis between 1980 and 2010 and the corresponding market reforms that governments enacted to comply with structural adjustment accords negotiated with the International Monetary Fund and World Bank are outlined below. In terms of civil society response to the reforms, there was a transition phase whereby new alliances were forged between the popular classes and emerging oppositional political parties in the late $1990 \mathrm{~s}$ and early $2000 \mathrm{~s}$. Specific attention is given to the economic threats posed by the market reforms in terms of deteriorating livelihoods for the working rural and urban classes (Shefner, Pasdirtz, and Blad 2006). The period from 1980 to the $2010 \mathrm{~s}$ was also characterized by greater levels of democratization and competitive elections in Central America. Sustained anti-neoliberal resistance campaigns did not occur until sufficient organizational power was created by a variety of social groupings, including, labor unions, public sector employees, women's collectives, students, NGOs, and oppositional political parties. These civil society associations and popular organizations used the emerging democratic spaces to shape new multi-sectoral alliances that could withstand pressure from the neoliberal state for their dismemberment.

The general pattern of these alliances is illustrated with experiences from Costa Rica, El Salvador, Guatemala, Honduras, Nicaragua, and Panama. These cases include mobilizations centered on free trade, price hikes, labor flexibility, privatization and extraction of natural resources. The mass resistance movements are embedded within the context of their broader interaction with large-scale economic shifts in the world system and represent a broader trend observed in South America and other regions of the democratizing global South. The article concludes by highlighting differences in the pace of social movement partyism across Central America in the era of free market globalization and the limits of social movement partyism once the opposition party takes executive power.

\section{Earlier Rounds of Integration into the World Capitalist System, 1940s-1980s}

Robinson (2003) has outlined the various phases of Central America's incorporation into the global capitalist economy since colonial rule through the early twenty-first century. After World War II, as elsewhere in the global South, the nations of Central America embarked on a path of state-led economic development. The process centered on an unprecedented expansion of state and economic infrastructure. This included the massive building of highways, public schools, hospitals, power grids, aqueduct systems, and other urban amenities. The period also witnessed a move away from reliance on a few agricultural exports (namely coffee and bananas) to a diversification in agricultural production with the expansion of sugar cane, beef, and cotton (Brockett 1998), as well as investments in light manufacturing industries, often through joint ventures with foreign capital. These efforts eventuated in sustained rates of economic growth in the $1950 \mathrm{~s}$ and $1960 \mathrm{~s}$ throughout the isthmus (Bulmer-Thomas 1987). Hence, the state-led development era in Central America initiated a new articulation with the world capitalist economy with the diversification of agricultural production and the emergence of an urban manufacturing sector (Robinson 2003). This marked a clear departure from the previous 


\section{Journal of World-Systems Research}

incorporation in the world system as peripheral provider of a reduced number of agricultural commodities in the late nineteenth and early twentieth centuries.

The 1940s to the 1980 s also witnessed the rise of organized social movements with the expansion of the state infrastructure, urbanization, light manufacturing, and agricultural diversification. Peasant cooperatives, labor unions, student groups, and public school teachers' associations grew markedly under state-led development throughout Central America. Guatemala experienced a short-lived democracy from 1944 to 1954 in which these civil society groups flourished (including the organization of the peasantry and the legalization of organized labor) until a U.S.-sponsored military coup (Gleijeses 1991). Costa Rica also enjoyed multi-party political competition in the period of state-led development, even though the Communist Party was banned from formal political participation until the mid-1970s. The Costa Rican state also encouraged agricultural sector mobilization in the $1960 \mathrm{~s}$ and $1970 \mathrm{~s}$ with its rural colonization program and legalization of banana worker unions. El Salvador and Nicaragua suffered under repressive military regimes, while Panama and Honduras oscillated between oligarchic political parties and military populism that at times mobilized urban and rural working classes (Almeida 2014). By the early $1980 \mathrm{~s}$, the state-led development model had largely reached exhaustion levels via the third world debt crisis, failed social reform, heavy state repression, and revolutionary conflicts (Robinson 2003).

In sum, in the state-led development era, resistance movements could be characterized as urban movements benefiting from modernization at times coalescing with the rural proletariat and small landholders. Electoral political parties challenging the distribution of wealth and international economic dependency were largely suppressed under authoritarian rule. ${ }^{1}$ Hence, the conditions for social movement partyism as a potent antisystemic resistance movement did not emerge until the global shift to free market democracy in the late twentieth century (Robinson 2006).

\section{The Current Round of Insertion into the Global Capitalist Economy and Multiple Rounds of Popular Resistance: 1980-2010}

With the global debt crisis of the 1980 s, Central American states were hampered by billions of dollars they owed in foreign loans. As elsewhere in the global South, the International Monetary Fund (IMF) and the World Bank stepped in to manage the crisis (Babb 2009). The main strategy for these international financial institutions centered on conditionality agreements or structural adjustment loans (SALs). SALs involved the re-negotiation of debts and future lines of credit for Central American states in exchange for free market reforms enacted on domestic economies. Early SALs in the 1980 s in the region included currency devaluations, price hikes, subsidy cuts on basic goods, agricultural inputs and transportation, wages freezes, and mass layoffs in the public sector. A new generation of SALs in the 1990s and 2000s used these same austerity policies in addition to privatization of much of the public sector and state-run industries (Bull 2008).

The consequences of these economic reforms emanating from core powers in the world system resulted in new transnational alliances between Central American capitalists and the global financial elite, especially in industries such as export manufacturing and processing zones, non-traditional agricultural crops, pharmaceuticals, tourism, and call centers (Robinson 2003;

\footnotetext{
${ }^{1}$ Even in relatively democratic Costa Rica in the state-led development era, the Communist Party (Partido Vanguardia Popular) was banned from electoral competition until 1975.
} 
Spalding 2014). The external debt also debilitated governments in Mesoamerica from sustaining vital social services in health, education, and utilities for the subaltern classes (Lehoucq 2012). Figure 1 demonstrates that all six Central American States were under some kind of structural adjustment agreement for the majority of years between 1980 and 2004 . $^{2}$ These structural adjustment pressures illustrated in Figure 1 provide the link between global neoliberalism, national economic policy and local mass resistance in the form of social movement partyism. In particular, within the SAL agreements, Central American states consented to privatize the state infrastructure, lift price controls on food, transportation, and utilities, engage in free trade, and open up natural resources to foreign investment and extraction. These types of arrangements empirically measured as "IMF Pressure" were associated with heightened outbreaks of austerity protest in the first decades of the global debt crisis throughout the developing world (Walton and Ragin 1990).

Figure1. Number of Years under IMF or World Bank Structural Adjustment Agreement, 1980-2004



Source: Figure constructed from Abouharb and Cingranelli (2007)

The first major sustained protest campaigns against structural adjustment erupted in Costa Rica and Panama in the 1980s, while El Salvador and Guatemala experienced short term campaigns of popular resistance. In Costa Rica, the popular classed assembled the first rounds of the social movement party-alliance against neoliberal reforms. Costa Rica entered a foreign debt crisis by the early 1980s (Spalding 2014). At the same time, the country's long standing democracy expanded political freedoms and political competition in the mid-1970s by legalizing leftist political parties. Several of these emerging socialist opposition parties would unify into the Pueblo Unido electoral coalition between 1978 and 1982. Pueblo Unido gained steam by

\footnotetext{
${ }^{2}$ The percentage of years under structural adjustment ranged between $56 \%$ (Guatemala) to $88 \%$ (Panama).
} 


\section{Journal of World-Systems Research}

supporting mobilization against the debt crisis especially in terms of battling subsidy cuts on vital urban services and necessities such as transportation, food, and electricity. This movementparty alliance peaked with the movement against IMF-sponsored price hikes in consumer electricity prices in mid-1983 (Alvarenga Venutulo 2005). Pueblo Unido party militants aligned with neighborhood organizations in dozens of towns and villages to oppose the austerity measures. The mobilizations included the construction of make-shift barricades on the country's major transportation corridors. The nation-wide mobilizations were potent enough to force the government to halt the measure and return prices to their pre-1983 levels.

As other countries began to democratize in the region in the $1990 \mathrm{~s}$, they followed a similar pattern as Costa Rica, leftist political parties aligned with popular movements to challenge the implementation of neoliberal policies issued by the IMF and World Bank. In some cases, the alliance benefited the electoral fortunes of the oppositional party. Hence, social movement partyism emerged as a key mode of resistance in the shift to global neoliberalism. For example, in Nicaragua, the Frente Sandinista de Liberación Nacional (FSLN) party immediately launched a massive campaign with labor unions and rural cooperatives in 1990 in response to newly elected president Violeta Chammoro's privatization and austerity measures. The national outpouring of popular unrest represented the largest collective actions since the revolution of 1979. Local level resistance to the neoliberal transition was more pronounced where the FSLN maintained a stronger territorial foothold and could mobilize popular organizations affiliated with the party (Almeida 2014).

By the $2000 \mathrm{~s}$, all six Central American states had democratized. At the same time, the international financial institutions were pushing a more aggressive form of privatization within structural adjustment accords as the external debt on the isthmus continued to increase (Almeida 2014). In particular, each country in the region came under pressure to begin privatizing and outsourcing strategic components of the state economic and social infrastructure that had expanded so markedly in the previous period of state-led development. Development scholars refer to the privatization policies dismantling the basic social, public, and economic infrastructure as a second generation of structural adjustment (Bello 2007). These privatizations included public lands, hospitals, telecommunications, energy production and distribution, water and aqueduct administration, ports, mail services, public works, and dozens of other state institutions and services. Some of these privatizations began in the $1990 \mathrm{~s}$ and went through with mild public opposition. However, by the $2000 \mathrm{~s}$, opposition political parties gathered enough potency to initiate campaigns of mass defiance against privatization and free trade throughout the region. The oppositional party-movement alliances were more extensive in Costa Rica, El Salvador, and Nicaragua. However, social movement partyism gained strength in Honduras, Panama, and Guatemala with the deepening of neoliberalism in the twenty-first century.

\section{Strong Cases of Social Movement Partyism (Costa Rica, El Salvador, and Nicaragua)}

\section{Costa Rica}

Costa Rica's road to social movement partyism is rooted in the campaigns against the debt crisis in the early $1980 \mathrm{~s}$ discussed above. A new round of social movement partyism began in 2000 with the historic struggle against the privatization of electricity and telecommunications in a single legislative package, referred to as "el Combo" by opponents (Almeida 2008; Frajam 
2009). Oppositional leftist parties played key roles in the mobilization including the Fuerza Democrática the Pueblo Unido Coalition, and small Trotskyist parties. Hundreds of roadblocks were erected around the country combined with mass marches to successfully force the government to backpedal and cancel its privatization plans. Local regions where leftist parties maintained territorial influence reported higher levels of resistance to privatization (Almeida 2012). Most significantly, the social movement and oppositional party mobilizations provided a blueprint on how to confront an even larger challenge to the survival of Costa Rica's tropical welfare state (Edelman 1999) - the threat of the Central American Free Trade Agreement (CAFTA). The key organizations and oppositional political parties that successfully overturned energy and electricity privatization formed a coordinating body (el Comité Nacional de Enlace) that provided the organizational seeds for the largest opposition to CAFTA on the isthmus. Also in the early 2000 s, two new left-of-center oppositional political parties emerged - the Citizens' Action Party (PAC) and the Frente Amplio. Both parties originated from public discontent with the neoliberal direction and corruption of the country's two long-standing traditional political parties (Lehoucq 2007).

By 2003, as the initial rounds of CAFTA were being discussed between the United States and governments of the region, mobilizations broke out on the streets of Costa Rica. By 2004, national campaigns against CAFTA were launched, while the PAC and Frente Amplio political parties publicly opposed the measures. PAC and Frente Amplio party members and legislative representatives often took part in the street marches against CAFTA - hand to hand with public school teachers, students, state employees, truck drivers, and ordinary citizens. The PAC almost won the presidency in early 2006 in a presidential campaign where CAFTA served as the principal public issue for debate, falling just one percentage point short of a victory over Oscar Arias and the long dominant (and pro-neoliberal) Partido de Liberación Nacional (PLN). Mobilizations continued building momentum against free trade in 2006 and 2007, including a two day-long general strike against CAFTA in October of 2006 that included actions in dozens of localities throughout the national territory. Mass mobilization reached historic levels in 2007 with two of the largest public demonstrations in modern Costa Rica history, reaching up to 150,000 people in February and September, respectively. The February 2007 mass march was so immense that it forced the government to hold a referendum on CAFTA.

In the second half of 2007 , the referendum resulted in renewed electoral mobilization between anti-CAFTA movements on the streets and the PAC and Frente Amplio political parties. These opposition parties mobilized the "No vote" in the referendum. This new social movement party mobilization was in the form of "Patriotic Committees" (Los Comités Patrióticos-local bastions of resistance to CAFTA at the community level in charge of getting out the vote in the "No" referendum campaign (Raventos 2013). CAFTA ultimately passed by a narrow margin in the popular vote of October 2007. After this time, a lull occurred in popular and electoral mobilization until the 2010s. Between 2008 and 2014, new struggles over open pit mining, water access, and privatization of highways and ports galvanized citizens to vote for left leaning parties in the 2014 elections whereby the leftist Frente Amplio won an unprecedented 9 parliamentary seats (out of 57) and the left-of-center Citizens' Action Party (PAC) won the presidency and 13 parliamentary seats. The socialist Frente Amplio party ran candidates for the legislative assembly that played major roles in the anti-systemic movements against mining, free trade, and privatization over the previous two decades. 


\section{Journal of World-Systems Research}

\section{El Salvador}

El Salvador entered the neoliberal order after over a decade of brutal civil war (1980-1992). The leftist insurgents of the Farabundo Martí National Liberation Front (FMLN) survived the war and converted into an electoral political party (Allison and Martin 2012). The new oppositional party continued to expand its electoral reach throughout the $1990 \mathrm{~s}$ winning greater representation in the national parliament and local governments. The FMLN often sided with social movement struggles against agricultural debt, privatization of pensions, telecommunications, and energy distribution and benefited with a growing electoral constituency.

By the end of 1999, the FMLN political party was on the front lines of a battle over health care privatization. The FMLN combated health care privatization from 1999 to 2003 in two massive social movement campaigns using the party's membership to mobilize on the streets and plazas against the neoliberal measures. The protests succeeded in halting health care privatization and eventuated in even more party success in the elections following the antiprivatization campaigns. Between 2003 and 2008, the party turned its mobilizing efforts to confronting the Central American Free Trade Agreement (CAFTA). The anti-CAFTA mobilizations included street marches, road blocks, and educational workshops. Even FMLN mayors participated in the protest activities. The party capitalized on this momentum to increase voter turnout in the 2004 and 2006 national elections, even though it did not harbor sufficient representation in parliament to prevent CAFTA's passage (Spalding 2014). In 2009, the FMLN won presidential power for the first time with nearly 1.3 million votes. In 2014 , the party triumphed for a second consecutive period, reaching a historic 1.5 million votes. Between 2009 and 2015, in the midst of the world financial crisis, the FMLN governments have worked to reduce poverty and resist further neoliberal measures such as the privatization of water and sewage administration, along with the implementation of many post-neoliberal social programs for the elderly, school children (e.g., paquetes escolares), the rural poor, and women (e.g., Ciudad Mujer).

\section{Nicaragua}

Nicaragua was baptized into the neoliberal era via counter-revolution. With the stunning presidential loss in the February 1990 elections, the revolutionary Sandinista (FSLN) party stepped down from power. The victorious neoliberal government of Violeta Chamorro unleashed a series of economic measures that slowly dismantled the cornerstones of the 1979 revolution. The policies included privatization of state-run farms, factories, and infrastructure. The FSLN immediately used its mass organizations to resist the neoliberal measures, resulting in a slower pace of the implementation of some of the reforms and greater concessions. These battles moved to the countryside by the mid-to late $1990 \mathrm{~s}$ as the neoliberal state de-funded state agricultural banks (Enríquez 2010). The FSLN as an oppositional party also tried to maintain the educational budget in the $1990 \mathrm{~s}$ and early $2000 \mathrm{~s}$ for the public universities that expanded during the revolution.

By the $2000 \mathrm{~s}$, former FSLN militants in the mass organizations, government offices, and the Sandinista army engaged in the NGO sector leading major campaigns against water and electricity privatization as well as consumer price hikes in utilities and transportation. These mobilizations resulted in greater electoral gains in the 2004 local elections and the 2006 national elections for the FSLN. In late 2006, the FSLN won the presidency and the party was re-elected 
in 2012. During this time in executive power, the FSLN has protected much of the remaining state infrastructure from further privatization programs and implemented a number of antipoverty and anti-hunger programs.

\section{Emergent Social Movement Partysim (Honduras, Panama, and Guatemala)}

\section{Honduras}

Neoliberal reforms in Honduras have also pushed political parties and movements into a close alliance. In 1990, the Honduran state made a decisive turn toward neoliberalism by enacting its first major structural adjustment agreements between the IMF and World Bank. A wave of sustained resistance resulted, but no major left-leaning electoral oppositional party existed at the time. In the end, between 1990 and 1993 a series of structural adjustment reforms (including energy and land privatization) were implemented by the Callejas government in one of the earliest phases of privatization in the region (Sosa 2010).

By the late 1990s a new left oppositional party emerged, the Unificación Democrática (UD) (Allison 2006). At the same time, the Honduran state initiated a second round of structural adjustment reforms with the international financial institutions between 1999 and 2004 in order to reduce its foreign debt and enter the Heavily Indebted Poor Countries (HIPC) initiative governed by the IMF and World Bank (Almeida 2014). Once again, popular organizations began to form alliances to battle the new neoliberal reforms. The two most important coalitions of popular organizations to develop were the Bloque Popular (formed in 1999) and Coordinadora Nacional de Resistencia Popular (established in 2003). The UD oppositional political party entered both of these coalitions. These multi-sectoral alliances fought several campaigns between 2000 and 2009 against privatization, price hikes, and the Central American Free Trade Agreement. Water privatization in particular, provided a central focus of the largest multisectoral mobilizations between 2003 and 2009. As elsewhere in Central America, the new round of free market policies emanating from the world economy and global financial institutions shaped the alliance between social movements and political parties in Honduras.

With the ascendancy and then overthrow of the populist Manuel Zelaya presidency in 2009, the party-movement alliance strengthened even further. Large factions of Zelaya's Liberal Party split off to join the Frente Nacional de Resistencia Popular (FNRP) along with the UD in a protest campaign to restore democracy. The threat to power-holders of social movement partyism as a major strategy of action resisting the military coup appeared so great that it resulted in the assassination of two party militants of Unificación Democrática (UD) in the cities of San Pedro Sula and Santa Barbara within weeks of the military ousting of Manuel Zelaya (Estrada 2012). The FNRP focused on building up sufficient social and political forces across the national territory to eventually take state power as an explicit goal. The FNRP sustained a two year battle against the military coup, renewed neoliberal policies and state repression.

With Zelaya's return to the country in mid-2011, an even more powerful social movement party was formed - the Libertad y Refundación (LIBRE) oppositional party. ${ }^{3}$ Between 2011 and 2014 the FNRP and LIBRE have largely focused on electoral mobilization. In particular, the LIBRE party used social movement mobilization against neoliberal measures in order to support electoral turnout. Indeed, Sosa Iglesias (2014) has documented an upturn in

\footnotetext{
${ }^{3}$ An overwhelming majority of UD party grassroots militants changed affiliation to the LIBRE party in 2011.
} 


\section{Journal of World-Systems Research}

social protest between 2012 and 2013 from 212 annual protest events to 497, respectively. This upsurge in popular contention occurred simultaneously with the presidential, parliamentary, and presidential election campaign of November 2013. In these historic elections, the LIBRE party broke up the 100 year old system of two party elite rule and became the second largest political party in Honduras campaigning on a platform of anti-neoliberalism and democratic socialism. This electoral appeal achieved nearly 900,000 votes for president and garnered the second largest number of parliamentary seats in the legislature. ${ }^{4}$

\section{Panama}

In Panama, anti-systemic movements emerged from struggles against labor flexibility, and privatization of energy, telecommunications, and water administration in the $1990 \mathrm{~s}$. By the 2000 s, popular movements used these experiences to build a powerful multi-sectoral coalition called the National Front in Defense of Social Security (FRENADESSO). FRENADESSO is a coalition of high school and university students, labor unions (including the militant construction workers in SUNTRACS), school teachers, and health care staff and professionals. Between 2003 and 2005 FRENADESSO fought two major battles against the restructuring and privatization of the Panamanian health and pension system-the Caja de Seguro Social (one of the more extensive social security systems in Latin America). The mobilizations reached across the national territory and served as a critical organizing experience for the next round of antineoliberal contention - the period between 2010-2014 with the arrival of the Martinelli government.

Beginning in 2010, another round of mass mobilization occurred in Panama over a new labor flexibility law that combined other anti-popular legislation such as watering down environmental laws and penalizing protests with harsh legal measures. The 2010 labor flexibility laws were followed by protests over mining contracts and hydroelectric dam construction in the Ngobe-Bugle Comarca in 2011 and 2012. These protests involved solidarity actions across the national territory and forced the government to backtrack on the mega-projects. Out of these anti-neoliberal struggles between 2003 and 2010 emerged a new left oppositional political party in early 2011 - the Frente Amplio por la Democracia (FAD). In late 2012, the Martinelli government and his majority Cambio Democrático Party in the parliament approved the privatization of lands surrounding the Canal Zone in the Province of Colon. The FAD party used its links in the popular movement to coordinate a massive nonviolent uprising against the privatization, leading to mobilizations throughout the country's nine provinces. The mobilizations were successful and the government overturned its plans for the privatizations. Nonetheless, the FAD was unable to convert its successful mobilizations on the streets into electoral victories. The party was only able to garner about 1 percent of the national vote in parliamentary and presidential elections in 2014.

\section{Guatemala}

The case of Guatemala is similar to Panama and Honduras (before the formation of LIBRE) with small leftist parties aligning with popular movements against major neoliberal reforms between 2000 and 2014. In particular the ANN and URNG oppositional parties have used their organizational structures to protest against new taxes (Almeida and Walker 2007), free trade, mining, and electricity price hikes. The oppositional parties have engaged with large multisectoral coalitions such as the MICSP and the FNL composed of dozens of civil society

\footnotetext{
${ }^{4}$ The author witnessed these elections as an international election monitor.
} 
organizations across the country (Yagenova 2015). These small left parties were weak at the dawn of neoliberalism in the $1980 \mathrm{~s}$ and $1990 \mathrm{~s}$ and unable able to overcome the massive state repression of the past or the fragmentation of the Guatemalan competitive party system (Allison 2006; Pallister 2013). The ANN and URNG (and smaller aligned parties such as Winaq) usually garner only between 3 and 10 percent of the popular vote in national elections. Nevertheless, with their high commitment followers scattered across Guatemala's 22 departments, these oppositional parties continue to hold national days of protest against mining and for the renationalization of energy distribution (including major nation-wide mobilizations in 2014 and 2015).

Table 1. Global Neoliberalism and Social Movement Partyism in Central America

\begin{tabular}{|c|c|c|}
\hline Country & $\begin{array}{l}\text { Neoliberal Policies that Led to the } \\
\text { Formation or Consolidation of } \\
\text { Social Movement Partyism }\end{array}$ & Social Movement Party \\
\hline Costa Rica & $\begin{array}{l}\text { Telecommunications and Electricity } \\
\text { Privatization, Central American Free } \\
\text { Trade Agreement, Mining, Ports and } \\
\text { Highway Privatization }\end{array}$ & $\begin{array}{l}\text { Fuerza Democrática/Frente } \\
\text { Amplio/Partido de Acción } \\
\text { Ciudadana (PAC) }\end{array}$ \\
\hline E1 Salvador & $\begin{array}{l}\text { Health Care Privatization, Central } \\
\text { American Free Trade Agreement, } \\
\text { Water Privatization }\end{array}$ & $\begin{array}{l}\text { Frente Farabundo Martí para la } \\
\text { Liberación Nacional (FMLN) }\end{array}$ \\
\hline Nicaragua & $\begin{array}{l}\text { Land Reform Privatization, Electricity } \\
\text { Privatization, Water Privatization, } \\
\text { Mass Transportation Subsidy Cuts }\end{array}$ & $\begin{array}{l}\text { Frente Sandinista de Liberación } \\
\text { Nacional (FSLN) }\end{array}$ \\
\hline Honduras & $\begin{array}{l}\text { Telecommunications Privatization, } \\
\text { Water Privatization, Model Cities } \\
\text { Program }\end{array}$ & $\begin{array}{l}\text { Unificación Democrática (UD), } \\
\text { Libertad y Refundación (LIBRE) }\end{array}$ \\
\hline Panama & $\begin{array}{l}\text { Water Privatization, Labor Flexibility, } \\
\text { Social Security/Health Care } \\
\text { Privatization, Mining, Land } \\
\text { Privatization }\end{array}$ & $\begin{array}{l}\text { Frente Amplio por la Democracia } \\
\text { (FAD) }\end{array}$ \\
\hline Guatemala & $\begin{array}{l}\text { Electricity Privatization, New Taxes, } \\
\text { Mining/Mega-Projects }\end{array}$ & FDNG/URNG/ANN \\
\hline
\end{tabular}

\section{Conclusion}

The shift from state-led development to neoliberal forms of capitalism at the global level provided new threats and incentives for antisystemic forces to form electoral political parties as a strategy to resist new harms associated with the loss of social citizenship rights. The concurrent process of democratization pushes subaltern groups to form oppositional political parties as one pathway to impede the process of neoliberalization. Table 1 summarizes the major neoliberal measures in Central America that unified oppositional parties with popular movements over the past two decades. Many of these policies emanating from the global shift toward deepening economic liberalization have motivated some of the largest outbreaks of popular unrest in 
modern Central America, especially over free trade and the privatization of health care, water, electricity and natural resources (Almeida 2014). The mobilizations have led to electoral triumphs for leftist opposition parties in El Salvador and Nicaragua, center-left parties in Costa Rica, and near leftist victories in Honduras and Costa Rica.

Nation-states with strong challenges from the left at the dawn of the shift to global neoliberalism in the $1980 \mathrm{~s}$ and $1990 \mathrm{~s}$ were able to form strong versions of social movement partyism at a rapid rate, as in the cases of Nicaragua and El Salvador. ${ }^{5}$ In countries with a two party system, the elite neoliberal parties had to weaken before a social movement party was able to gain substantial strength, as the cases of Costa Rica and Honduras illustrate. ${ }^{6}$ Even countries with small left-wing parties, such as Guatemala and Panama, the oppositional parties have played a fundamental role in mobilizing popular sectors against major free market reforms such as privatization, free trade, and foreign extraction of natural resources, even if they have yet to convert social movement mobilization into major electoral victories. As elsewhere in Latin America and other regions of the global South, Central America demonstrates an innovative mode of mass resistance emerging between party and movement with the world historical transformation from state-led development to a renewed cycle of accumulation centered on privatization and free trade.

A logical next step for the analysis of social movement partyism would be to examine the party-movement relationship once the oppositional party takes power (Levistky and Roberts 2011; Prevost, Vanden, and Campos 2012; Goodale and Postero 2013). For the most part social movement activity has declined in the countries where the left has taken power. This partially indicates that in our cases of strong social movement partyism, much of the prior anti-neoliberal mobilization emanated from the political parties with their ability to "chill out" mobilization after electoral triumph. The left parties in El Salvador, Nicaragua, and to some extent in Costa Rica, originated out of social movements with many rank and file members simultaneously party affiliates and activists in civil society organizations.

In Central America, even when left-leaning governments have taken power in Costa Rica, El Salvador, and Nicaragua they still operate their national economies within the broad parameters of CAFTA and the larger capitalist world system. Even though major reforms have been implemented in Nicaragua and El Salvador (such as Zero Hunger, low interest loans to the rural sector, minimum allowances to the elderly, and school food and uniform programs, etc.), the "post-neoliberal" states still are largely organized along free market lines. Scholars view the social movement party mobilizations and their reformist outcomes in Central and South America as resembling more of Polanyian-type struggle of reducing the most harmful impacts of unregulated markets - such as the sharp social cuts associated with neoliberalism of the early

\footnotetext{
${ }^{5}$ The case of Nicaragua also has some variation over time with the pact between Daniel Ortega and Arnoldo Alemán's Liberal Party (Marti Puig 2015). At times the "pact" was used by the FSLN to demobilize street protests, especially in the late 1990s and against CAFTA in the mid-2000s. The Pact also divided the Liberal Party making Ortega and the FSLN's election victory achievable in late 2006. In El Salvador, the FMLN's electoral success is also due to the party's ability to reach out to sectors beyond its traditional base such as business sectors and groups alienated with the long dominant ARENA party. The choice of presidential candidate Mauricio Funes for the 2009 presidential elections demonstrated this willingness of the party to move beyond its core base of supporters. ${ }^{6}$ The case of Honduras is somewhat unique in that the military coup of 2009 gave a great boost to the scale of social movement partyism by Zelaya's ability to pull a substantial portion of the traditional Liberal Party into the social movement party of LIBRE. Nonetheless, the party movement alliance had already been formed on a much smaller scale between the UD and popular movements - a relationship that centered on mobilizing against neoliberal measures implemented in the period from 1999-2009.
} 
twenty-first century (Silva 2009; Spalding 2014). ${ }^{7}$ Systematic empirical evidence is also mounting that reformist governments in Latin America are effectively reducing poverty levels and increasing social well-being as observed in measures of health and educational outcomes (Flores Macías 2012; Cohn 2012; Huber and Stephens 2012).

\section{References}

Abouharb, M. Rodwan., and David Cingranelli. 2007. Human Rights and Structural Adjustment. Cambridge: Cambridge University Press.

Agartan, Tuba, Woo-Young Choi, and Tu Huynh. 2008. "The transformation of the capitalist world: 1750-1850." Pp. 10-49 in W. Martin, ed., Making Waves: Worldwide Social Movements, 1750-2005. Boulder, CO: Paradigm.

Allison, Michael. 2006. "The Transition from Armed Opposition to Electoral Opposition in Central America." Latin American Politics and Society 48(4): 137-162.

Allison, Michael and Alberto Martin Alvarez. 2012. "Unity and Disunity in the FMLN." Latin American Politics and Society 54(4): 89-118.

Almeida, Paul D. 2014. Mobilizing Democracy: Globalization and Citizen Protest. Baltimore: Johns Hopkins University Press.

. 2012. "Subnational Opposition to Globalization." Social Forces 90(4): 1051-1072.

2010. "Social Movement Partyism: Collective Action and Political Parties." Pp. 170-196

in N. Van Dyke and H. McCammon, eds., Strategic Alliances: New Studies of Social Movement Coalitions. Minneapolis: University of Minnesota Press.

. 2008. "The Sequencing of Success: Organizing Templates and Neoliberal Policy Outcomes."Mobilization 13(2): 165-187.

. 2007. "Defensive Mobilization: Popular Movements against Economic Adjustment

Policies in Latin America." Latin American Perspectives 34(3): 123-139.

. 2006. "Social Movement Unionism, Social Movement Partyism, and Policy Outcomes."

Pp. 57-73 in H. Johnston and P. Almeida, eds., Latin American Social Movements:

Globalization, Democratization, and Transnational Networks. Lanham, MD: Rowman and Littlefield.

Almeida, Paul D. and Erica Walker. 2007. "El Avance de la Globalización Neoliberal: Una Comparación de Tres Campañas de Movimientos Populares en Centroamérica." Revista Centroamericana de Ciencias Sociales 4(1): 51-76.

Alvarenga Venutolo, Patricia Ana. 2005. Los ciudadanos y el estado de bienestar: Costa Rica en la segunda mitad del siglo XX. San José: Editorial Universidad de Costa Rica.

Arrighi, Giovanni,Terence K. Hopkins and Immanuel Wallerstein 1989. Anti-Systemic Movements. London: Verso.

Babb, Sarah. 2009. Behind the Development Banks: Washington Politics, World Poverty, and the Wealth of Nations. Chicago: University of Chicago Press.

Bello, Walden. 2007. "The post Washington Dissensus." Focus on Trade 132.

\footnotetext{
${ }^{7}$ Another interesting outcome to examine would be the international relationships between social movement partyism and other leftist governments and anti-neoliberal alternatives such as ALBA in terms of the effectiveness of social movement partyism and the success of reformist governments after an electoral triumph.
} 
Block, Fred and Margaret Somers. 2014. The Power of Market Fundamentalism : Karl Polanyi's Critique. Cambridge, MA: Harvard University Press.

Bob, Clifford. 2005. The Marketing of Rebellion: Insurgents, Media, and International Activism. Cambridge: Cambridge University Press.

Brockett, Charles. 1998. Land, Power, and Poverty: Agrarian Transformation and Political Conflict in Central America. 2nd ed. Boulder, CO: Westview Press.

Bull, Benedicte. 2005. Aid, Power, and Privatization: The Politics of Telecommunication Reform in Central America. Northampton, MA: Edward Elgar.

Bulmer-Thomas, Victor. 1987. The Political Economy of Central America since 1920. Cambridge: Cambridge University Press.

Bush, Caleb. 2008. "Reformers and Revolutionaries: The Rise of Anti-Systemic Movements and the Paradox of Power, 1848-1917." Pp. 50-81 in W. Martin, ed., Making Waves: Worldwide Social Movements, 1750-2005. Boulder, CO: Paradigm.

Chase-Dunn, Christopher. 2006. "Globalization: A World System Perspective." Pp. 79-105 in C. Chase-Dunn and S. Babones, eds, Global Social Change: Historical and Comparative Perspectives. Baltimore: Johns Hopkins University Press.

Cohn, Samuel. 2012. Employment and Development under Globalization: State and Economy in Brazil. London: Palgrave.

Diani, Mario and Maria Kousis. 2014. "The Duality of Claims and Events: The Greek Campaign against Troika's Memoranda and Austerity, 2010-2012." Mobilization 19(4): 387 -404.

Edelman, Marc. 1999. Peasants against Globalization. Stanford, CA: Stanford University Press.

Enríquez, Laura. 2010. Reactions to the Market: Small Farmers in the Economic Reshaping of Nicaragua, Cuba, Russia, and China. University Park: Pennsylvania State University Press.

Estrada, Oscar. 2012. Honduras: Crónicas del golpe de Estado y Resistencia. Brimfield, MA: Casasola Editores.

Flores Macías, Gustavo. 2012. After Neoliberalism?: The Left and Economic Reforms in Latin America. Oxford: Oxford University Press.

Foran, John. 2005. Taking Power: On the Origins of Third World Revolutions. Cambridge: Cambridge University Press.

Frajman, Eduardo. 2009. Information and Values in Popular Protests: Costa Rica in 2000. Bulletin of Latin American Research 28(1): 44-62.

Gleijeses, Piero. 1991. Shattered Hope: The Guatemalan Revolution and the United States, 1944-1954. Princeton, N.J.: Princeton University Press.

Goodale, Mark and Nancy Postero. Eds. 2013. Neoliberalism Interrupted: Social Change and Contested Governance in Contemporary Latin America. Palo Alto: Stanford University Press.

Gunder Frank, Andre and Marta Fuentes. 1994. "On Studying the Cycles in Social Movements." Research in Social Movements, Conflicts and Change 17: 173-196.

Huber, Evelyne, and John Stephens. Democracy and the Left: Policy and Inequality in Latin America. Chicago: University of Chicago Press.

Hulme, David, and Michael Edwards. Eds. 1997. NGOs, States and Donors: Too Close for Comfort. London: St. Martins

Huntington, Samuel P. 1991. The Third Wave: Democratization in the Late Twentieth Century. Norman: University of Oklahoma Press. 
Jackson, Jeffrey T. 2005. The globalizers: development workers in action. Baltimore: Johns Hopkins University Press.

Kousis, Maria. 2014. "The Transnational Dimension of the Greek Protest Campaign against Troika Memoranda and Austerity Policies, 2010-12." In D. della Porta and A. Mattoni (eds) Spreading Protests in Social Movements of the Crisis, Colchester: ECPR Press.

Lehoucq, Fabrice. 2012. The Politics of Modern Central America: Civil War, Democratization, and Underdevelopment. Cambridge: Cambridge University Press. .2007. Policymaking, parties and institutions in democratic Costa Rica. Mexico City: Centro de Investigación y Docencia Económicas.

Levitsky, Steven, and Kenneth Roberts. 2011. "Introduction: Latin America's 'Left Turn': A Framework for Analysis," in The Resurgence of the Latin American Left, 1-30. Baltimore: Johns Hopkins University Press.

Markoff, John and Amy White. 2009. "The Global Wave of Democratization."Pp. 55-73 in Christian W. Haerpfer, Ronald Inglehart, Chris Welzel and Patrick Bernhagen, eds., Democratization in a Globalized World. Oxford: Oxford University Press.

Marti Puig, Salvador. 2015. "Social Movements in Nicaragua (1979-2014): an Exceptional Case." In P. Almeida and A. Cordero. Eds. Handbook of Social Movements across Latin America. New York: Springer.

Martin, William. 2008. "Conclusion: World Movement Waves and World Transformations." Pp.168-180 in W. Martin, ed., Making Waves: Worldwide Social Movements, 1750-2005. Boulder, CO: Paradigm.

Nepstad, Sharon Erickson. 2011. Nonviolent Revolutions: Civil Resistance in the Late Twentieth Century. Oxford: Oxford University Press.

Pallister, Kevin. 2013. "Why No Mayan Party? Indigenous Movements and National Politics in Guatemala. Latin American Politics and Society 55(3): 117-138.

Prevost, Gary, Carlos Oliva Campos, and Harry Vanden, eds. 2012. Social Movements and Leftist Governments in Latin America: Confrontation or Co-optation? London: Zed.

Raventos, Ciska. 2013. " 'My Heart Says No': Political Experiences of the Struggle against CAFTA-DR in Costa Rica." In J. Burrell and E. Moodie, eds., Central America in the New Millennium: Living Transition and Reimagining Democracy, 80-95. New York: Berghahn.

Robinson, William. 2003. Transnational Conflicts: Central America, Social Change, and Globalization. London: Verso. . 2006. "Promoting Polyarchy in Latin America: The Oxymoron of "Market Democracy."" In (eds.) Eric Hershberg and Fred Rosen Latin America After Neoliberalism. New York: The New Press.

Schock, Kurt, 2005. Unarmed Insurrections: People Power Movements in Nondemocracies. Minnesota: University of Minnesota Press.

Shefner, Jon and Julie Stewart. 2011. "Neoliberalism, Grievances and Democratization: An Exploration of the Role of Material Hardships in Shaping Mexico Democratic Transition." Journal of World Systems Research 17(2): 353-378.

Shefner, Jon, George Pasdirtz, and Cory Blad. 2006. "Austerity Protests and Social Immiseration: Evidence from Mexico and Argentina". In Latin American Social Movements, edited by Hank Johnston and Paul Almeida. Lanham, MD: Rowman \& Littlefield. 
Silva, Eduardo. 2012. "Exchange Rising? Karl Polanyi and Contentious Politics in Contemporary Latin America. Latin American Politics and Society 54(3): 1-32.

Silver, Beverly. 2003. Forces of Labor: Workers'Movements and Globalization since 1870. Cambridge: Cambridge University Press.

Smith, Jackie, and Dawn Wiest. 2012. Social Movements in the World System: The Politics of Crisis and Transformation. New York: Russell Sage Foundation.

Sosa, Eugenio. 2010. La protesta social en Honduras: del ajuste al golpe de estado. Tegucigalpa: Editorial Guaymuras.

Sosa Iglesias, José Eugenio. 2014. "Honduras: Entre criminalidad, enfrentamiento mediático, protesta social y resultados electorales cuestionados." Revista de Ciencia Politica 34(1): $203-219$.

Spalding, Rose. 2014. Contesting Trade in Central America: Market Reform and Resistance. Austin: University of Texas Press.

Subramaniam, Mangala. 2015. "Introduction: States and Social Movements in the Modern World-System" Journal of World System Research.

Subramaniam, Mangala. 2007. "NGOs and Resources in the Construction of Intellectual Realms: Cases from India" Critical Sociology 33 (3): 551-73.

Udayagiri, Mridula, and John Walton. 2003. "Global transformation and local counter movements: the prospects for democracy under neoliberalism." International Journal of Comparative Sociology 44(4): 309-343.

Wallerstein, Immanuel. 1990. "Antisystemic Movements: History and Dilemmas." Pp. 13-53 in S. Amin, G. Arrighi, A. Gunder Frank, and I. Wallerstein, eds., Transforming the Revolution: Social Movements and the World System. New York: Monthly Review Press. . 2014. "Anti-systemic Movements, Yesterday and Today." Journal of World Systems Research 20(2):158-172.

Walton, John, and Charles Ragin. 1990. "Global and National Sources of Political Protest: Third World Responses to the Debt Crisis." American Sociological Review 55(6): 876-91.

Yagenova, Simona. 2015. "Guatemalan social movements: From the peace process to a new cycle of popular struggle, (1996-2013)." In P. Almeida and A. Cordero, eds. Handbook of Latin American Social Movements. New York: Springer. 